\title{
Entrepreneurial Leadership: A Review of Measures, Antecedents, Outcomes and Moderators
}

\author{
Sushant Ranjan \\ ${ }^{1}$ Indian Institute of Management, Rohtak, India \\ Correspondence: Sushant Ranjan, Indian Institute of Management, Rohtak, Management City, Southern Bypass, \\ NH 10, Sunaria, Rohtak, Haryana 124001, India. Tel: 91-90-5073-1894. E-mail: fpm04.012@iimrohtak.ac.in
}

Received: October 18, 2018

Accepted: November 9, $2018 \quad$ Online Published: November 29, 2018

doi:10.5539/ass.v14n12p104

URL: https://doi.org/10.5539/ass.v14n12p104

\begin{abstract}
The current study presents the review on entrepreneurial leadership since year 1980. Concept of entrepreneurial leadership, and its development so far were captured. Drawing on the comprehensive literature review of 50 studies, we have presented the measures used in the prior literature to capture the main construct of entrepreneurial leadership. Dimensions such as strategic factors, communicative factors, personal factors, motivational factors and leadership behaviors contribute to form entrepreneurial leadership. Various antecedents of entrepreneurial leadership such as human capital, social capital, entrepreneurial mindset, ambidexterity, and uncertainty absorbing, challenge framing, clearing path, commitment building and limits specification were identified. Outcomes such as wealth creation, strategic management of resources, innovation performance, startup performance and creativity were also identified. The possible traits of entrepreneurial leaders such as performance oriented, ambitious, informed, extra insight visionary foresight, confidence builder, diplomatic, effective bargainer, convincing, encourage, inspirational, enthusiastic, team builder, improvement-oriented, integrator, intellectual stimulation and positive attitudes are found.
\end{abstract}

Keywords: Entrepreneurial leadership, entrepreneur, leadership, entrepreneurial leader

\section{Introduction}

The term entrepreneur originates due to emergence of new business or startups. Entrepreneur is defined as individual who has started a novel firm or company (Cunningham \& Lischeron, 1991). While novel firm means business where no person has been before entered into the same business. Entrepreneurs are considered to be a great person as they are always active in presenting notion or novel ideas. Their novel ideas let other find engrossment with their new beliefs.

Cunningham \& Lischeron (1991) have presented schools of thought on entrepreneurship. Entrepreneurs are bestowed with characteristics such as their ability of intuition, need for achievement, ready to handle risk, surviving in turbulent market and presence of specific traits makes separates them from other individuals. Having the ability to innovate and creative mind mold their entrepreneurial behavior for early growth business and start-up. They are also considered to be good at planning, capitalizing, organizing people and preparing budgets. Since the entrepreneurs can't effectuate their goals in isolation, but are dependent and requires followers. In line with leadership school of thought, having the ability to motivate, direct and lead, makes them leaders of humankind.

Entrepreneurial leadership has been defined as ability to manage the resources available for seeking opportunity and advantage in an strategic manner (Ireland, Hitt, \& Sirmon, 2003). According to this definition, entrepreneurial leadership can be applied to every type of firms independent of the size of the firm. Entrepreneurial leaders are having provocations related to the enactment of scenario and cast and should be able to seek opportunities, make the vision and create situations. Leaders of entrepreneurial orientation persuade stakeholders and followers to achieve the goal by acknowledging and exploiting the opportunities concealed behind the scenario (Gupta, MacMillan, \& Surie, 2004). Wang, Tee, \& Ahmed (2012) and Mccarthy et al. (2010) defined entrepreneurial leadership as the ability of an individual to influence others to make the usage of the resources in an strategic manner. Entrepreneurial leadership has been presented to be existing at the junction of leadership and entrepreneurship (Leitch \& Volery, 2017). 
According to Surie \& Ashley (2012), entrepreneurial leaders are team oriented, value based and neo-charismatic in nature. Neo-charismatics leadership deals with ability to integrate the followers and leaders together for mutual consent. Team oriented approach deals with the ability of a leader to achieve high involvement of members in the team. Entrepreneurial leadership is based on value, thus articulating and reinforcing the mission and vision by enhancing the confidence of conviction of followers in meet the leader's expectation.

Entrepreneurial leaders have both the ability of cognition and are highly motivated. The cognitive ability of leaders allows them to evaluate the opportunity, discover and create the venture and growth of the same. They are capable of making mental models through their experience and tacit knowledge they are having. The presence of motivation in allows them to use their expertise for productive use (Koryak et al., 2015). Destler \& McArthur ( 1946) have investigated 43 entrepreneurs and found certain practices carried out by entrepreneurial leaders. The activities such as innovation, development of monopoly techniques, development of sound corporate finance, political corruption, manipulation of the government and press were undertaken by the entrepreneurs to achieve success.

Although the past literature has focused on entrepreneurial leadership there is dearth of the study on entrepreneurial leadership. We extracted opportunity from the past literature by reviewing the clarity over entrepreneurial leadership. Moreover we investigated and identified the measures, antecedents, outcomes and moderators of entrepreneurial leadership, which have been not captured in the previous literature yet.

In the current study, we started the review with the presentation of the concept of Entrepreneurial Leadership and it's development. The structure of the study is as follows: section 2 provides major findings across the literature on entrepreneurial leadership. Section 3 provides a description of the research methodology used in the current study. Section 4.1 presents the description of the existing measures of the entrepreneurial leadership. Section 4.2 describes antecedents to the entrepreneurial leadership. Section 4.3 identifies the possible outcomes of entrepreneurial leadership. Section 4.4 provides certain possible moderators of entrepreneurial leadership. Next we concluded the study in section 5 .

\section{Major Findings Across Literature on Entrepreneurial Leadership}

Entrepreneurial studies has been growing since 1980 (Charan, Hofer, \& Mahon, 1980). In line with some of the significant findings around entrepreneurial leadership and related field, 841 youth aging from 14 to 19 were examined through telephonic interviews. The author has found the black youth are more desperate and interested in starting the business (Waistad \& Kourilsky, 1998). Youths have a perception that successful entrepreneurs need to give back to society. There is a need for entrepreneurial studies as part of the education to clear the misconceptions of the young generation (Boni, Weingart, \& Evenson, 2009; Waistad \& Kourilsky, 1998).

Previous literature has tried to bring the importance of innovation for business. Innovation is a vital function of entrepreneurial leadership whether the business is existing, early growth or public service institutions (Durker, 2015).

Through a case study on family business, the importance of procedural justice (Van der Heyden, Blondel, \& Carlock, 2005) and shared meaning of "who we are as a family business" (Shepherd \& Haynie, 2009) for the resolution of conflict and enhancing the performance of the family business is suggested.

Through the investigation of 276 nascent entrepreneurs, pre-venture planning has been found to be related to persistence in the new venture (Gartner \& Liao, 2017). Nascent entrepreneurs who have completed business plan at an early stage are more likely to persist as compared to entrepreneurs who have no idea.

Importance of gender in the venture process is covered in the past studies (Brush, 2002; Galloway, Kapasi, \& Sang, 2015; Hamilton, 2006; Lechner, Sortheix, Obschonka, \& Salmela-Aro, 2018; Lewis, 2015; Mcgowan, Cooper, Durkin, \& O'Kane, 2015). The relation of gender with the entrepreneurial leadership has been explored in the past and it has been found it is the passion of the leaders rather than gender can make entrepreneurial success through altercation to the lives of people, customers and other entrepreneurs in the society (Bodolica \& Spraggon, 2015; Dean \& Ford, 2017).

Creativity has been found to be one of the possible outcomes in the study of 191 pairs of employees and leaders of Chinese firms and it has been concluded that the behavior of entrepreneurial leader is significantly related to the creativity of employees (Wu, McMullen, Neubert, \& Yi, 2008).

Various studies in the past have uncovered the importance of social, human capital and financial capital influencing the funding of new firms, categories of financing, time for new firms to get the IPO and emergence of young women as entrepreneurial leaders in business (Gartner, 2011; Jayawarna, Jones, \& Macpherson, 2011; Mcgowan et al., 2015; Nicholls, 2010; Yang, Zimmerman, \& Jiang, 2011; Yang, Zhou, \& Zhang, 2015). 
Distributed leadership, transactional and transformational and laissez-faire leadership, and charismatic leadership were also found to influence the performance of business apart from entrepreneurial leadership (Cope, Kempster, \& Parry, 2011; Yang et al., 2015; Zaech \& Baldegger, 2017).

\section{Research Methodology}

The objective of the present study is to examining the literature on entrepreneurial leadership, identifying measures to capture the construct of entrepreneurial leadership and the related construct, describing the precursors, outcomes and moderators of an entrepreneurial leaders.

A comprehensive literature review was performed to achieve the objective. The literature reviewed in the present study includes journal articles. Articles from the journals of ABDC A*A and B category are reviewed as the inclusion criteria. In all, a total of 50 studies from the year 1980 to 2017 were examined for the current study.

Identification of the relevant literature was captured after investigating through the databases for the keywords "Entrepreneurial Leadership" and "Entrepreneurial leader". The databases captured for the same are:

- $\quad$ EBSCO

- Scopus

- JSTOR

- Science Direct

- ABI/Inform: Pro Quest

- $\quad$ Emerald Insight

- Google Scholar

4. Examining the Study

4.1 Existing Measures of Entrepreneurial Leadership and the Related Construct

Table 1. Summary of existing measures of entrepreneurial leadership

\begin{tabular}{cccc}
\hline Study & Concept Measured & Main Construct & Number of items \\
\hline (Gupta et al., 2004) & Attributes of a leader & Entrepreneurial Leadership & 19 \\
& Strategic Factors, & & 39 \\
(Amir et al., 2012) & $\begin{array}{c}\text { Communicative Factors, } \\
\text { Personal Factors and }\end{array}$ & Entrepreneurial Leadership & 36 \\
& Motivational Factors & & \\
(Zaech \& Baldegger, 2017) & Leadership behavior & Behavior of Leaders of Startup Firms & 8 \\
& Innovativeness-3, & Entrepreneurial & \\
(Renko et al., 2015) & Creativity-2, Passion-1, & Leadership-ENTRELEAD Scale & \\
& Vision of future-1, Taking & Risks-1 & \\
\hline
\end{tabular}

- $\quad$ Prior literature has presented different measures to capture entrepreneurial leadership. Gupta et al. (2004) has presented measure of entrepreneurial leadership through 19 attributes under the taxonomy of five roles. The construct has been studied in the cross-cultural context across middle managers. After evaluation of the universality of the construct, the author found universal partly support for the construct at the individual level and full support at an organizational level and society level.

- Zaech \& Baldegger (2017) has referred to Bass (1985) for measuring the behavior of leaders. The construct was operationalized with the help of MLQ (Multifactor Leadership Questionnaire) developed by Bass (1985) to measure the behavior of CEOs and employees of startup firms. Leadership behavior was assessed using 36 items under the dimension of transformational leadership, laissez-faire leadership, and transactional leadership.

- Amir, Hejazi, Maleki, \& Naeiji (2012) have developed the measure to capture entrepreneurial leadership. The scale contains 39 items under four dimensions for measuring entrepreneurial leadership: strategic factors with 10 items (e.g.; "Assigning vision for followers"), communicative Factors (e.g., "the ability to persuade followers"), personal factors (e.g.; "open mind in dealing with events") and motivational factors (e.g.; "self-confidence to influence others"). Construct has met the reliability criteria as Cronbach's Alpha Value of all the factors were greater than 0.70 . 
- Renko, El Tarabishy, Carsrud, \& Brännback (2015) have designed the measure of entrepreneurial leadership popularly knows as ENTRELEAD Scale. Five factors with total of 8 items were developed. Factors namely innovativeness (e.g.; "often comes up with radical improvement ideas for the products/services we are selling"), creativity (e.g.; "has creative solutions to problems"), passion (e.g.; "demonstrates passion for his/her work"), vision of future (e.g.; "has a vision of the future of our business") and taking risks (e.g.; "takes risks") together determines the main construct.

\subsection{Possible Precursors to Entrepreneurial Leadership}

Gupta et al. (2004) found different roles of leaders leading to the development of Entrepreneurial leadership. The study has found certain roles pertaining to the entrepreneurial leaders, such as challenge framing, uncertainty absorbing, clearing path, commitment building and limits specification. We propose that presence of specific attributes and functions in a leader may lead to entrepreneurial leadership. Some of the roles have been discussed below:

\subsubsection{Challenge Framing}

Leaders stabilize the growth and productivity of the team with the capability of the team. The role of a leader is to frame the challenge towards group and followers in a balanced way. The challenge should not push the team members and followers beyond their limits, preferably within the limit of their capabilities.

\subsubsection{Uncertainty Absorbing}

Leaders are ready to absorb the responsibility of the uncertainty of the future. Providing the vision for future to the followers, which is to accept by the followers. Leaders take responsibility for unreliable future if anything goes wrong due to followers.

\subsubsection{Clearing Path}

Entrepreneurial leader provide a clear path to the followers for achieving the goal. Leader works out with environment inside as well as outside the firm to obtain necessary information and resources. The leader negotiates with the internal and external stakeholders to clear barriers present in the path of goal achievement.

\subsubsection{Commitment Building}

Entrepreneurial leader helps in building commitment of the followers by inspiring them, enhancing their effort and energy in achieving the scenario enacted by the entrepreneur leader.

\subsubsection{Limits Specification}

Creativity thrives when some constraints are applied. Specifying limit according to the capability of the team and followers enhances creativity of followers. The role of leader in defining the limits helps the followers to maintain their commitment to the turbulent environment.

The above five roles of a leader can enhance their entrepreneurial leadership. Apart from these roles, entrepreneurial mindset and specific attributes in a person lead to entrepreneurial leadership (Gupta et al., 2004; Shepherd \& Haynie, 2009).

\subsubsection{Entrepreneurial Mindset}

Entrepreneurial mindset aids managers to take effective action according to the situation in the contingent environment. Hard work, independence, and personal risk-taking together constitute to form entrepreneurial mindset of leaders. The presence of this mindset enhances entrepreneurial leadership.

\subsubsection{Human Capital}

Human capital has been found to be influencing the emergence of young women as entrepreneurial leaders. Human Capital here refers to the capital available to a person regarding his experience and knowledge extracted so far. It also includes capital in the form of demographic attributes such as gender and age, and education, skills and training. Human acts as forerunner to entrepreneurial leadership (Mcgowan et al., 2015). The human capital available to a person is crucial for the development and successful business venturing.

\subsubsection{Social Capital}

Social capital deals with the relationship an individual is having in the social group. Presence of business network developed through information sharing and liaison between the individual and other actors in network is crucial for prosperous business venturing. Social capital is imperative for efficacious leaders in their business for furnishing critical resources available to the firm in the form of financial and human to a firm. Thus human and social capital is consequential for the very growth of entrepreneurial leadership. 


\subsubsection{Institutional Capital}

Leitch, Mcmullan, \& Harrison (2013) argues that without the institutional capital human capital of a leader comes to stake. It is the set of procedures, rules and formal structures, which intensify the impact of social capital, and amplifies the human capital of a leader. Hence, development of entrepreneurial leadership also depends on institutional capital.

\subsubsection{Susceptibility of Followers}

Susceptibility of followers to the entrepreneurial opportunities provides conducive environment to the development of entrepreneurial leadership. It is the interaction of leaders and followers which determines the achievement of goals of entrepreneurial leadership (Renko et al., 2015)

\subsubsection{Ambidexterity}

In the study of Dean \& Ford (2017) six entrepreneurial leaders were examined with structured observation. Presence of competency in pursuing both exploration and exploitation of resources determines the effectiveness of entrepreneurial leadership.

\subsubsection{Learning}

Development of robust entrepreneurial leadership depends on entrepreneurial learning possessed by the leader. Experience, social interaction and ability to reflect on after observing the issues and opportunities constitutes entrepreneurial learning which leads to entrepreneurial leadership (Bagheri \& Pihie, 2011; Kempster \& Cope, 2010).

\subsubsection{Emotions}

Emotions at a time also predict the development of entrepreneurial leadership. Emotional stability during business failure and learning from the same is required at the individual level. The emotions and ability to handle it can greatly impact success of entrepreneurial leadership (Huxtable-Thomas and Hannon, 2016).

\subsubsection{Work Values}

Work values are the significance an individual gives to the attributes of his work and recompense that he receives from his work. Work value has been found to contribute to the development of entrepreneurial leadership (Lechner et al., 2018).

Table 2. Summary of antecedents of entrepreneurial leadership

\begin{tabular}{ll}
\hline Antecedents & References \\
\hline Challenge Framing & (Gupta et al., 2004) \\
Human Capital & (Mcgowan et al., 2015), (Yang, Zhou, \& Zhang, 2015), (Nicholls, 2010), \\
& (Yang, 2011; Zimmerman, \& Jiang, 2011), (Leitch et al., 2013), \\
Uncertainty Absorbing & (Gupta et al., 2004) \\
Ambidexterity & (Dean \& Ford, 2017) \\
Clearing path & (Gupta et al., 2004 \\
Entrepreneurial Mindset & (Shepherd \& Haynie, 2009) \\
Commitment Building & (Gupta et al., 2004 \\
Limits specification & (Gupta et al., 2004 \\
Social Capital & (Mcgowan et al., 2015), (Jayawarna, Jones, \& Macpherson, 2011), (Leitch et al., 2013), \\
& (Vecchio, 2003), (Prabhu, 1999) \\
Institutional Capital & (Leitch et al., 2013) \\
Susceptibility of followers & (Renko et al., 2015) \\
Entrepreneurial Learning & (Bagheri \& Pihie, 2011), (Huxtable-Thomas \& Hannon, 2016), (Kempster \& Cope, 2010) \\
Emotions & (Huxtable-Thomas \& Hannon, 2016) \\
Work values & (Lechner et al., 2018) \\
\hline
\end{tabular}

\subsection{Possible Outcomes of Entrepreneurial Leadership}

\subsubsection{Strategic Management of Resources}

As discussed in the previous section, the presence of capital in the form of human and social aids the development of sound entrepreneurial leadership. With the presence of these capitals, an entrepreneurial leader 
identifies the entrepreneurial opportunities around them. Since competitive advantage of a firm depends on the how a leader can acquire and develop the resources after identifying them (Ireland et al., 2003).

\subsubsection{Wealth Creation}

The presence of human and social capital and ability to identify the resources in the entrepreneurial leader is not enough to enhance firm performance. The entrepreneurial leaders' ability to manage the resources strategically affects the performance of the business by creating wealth (Ireland et al., 2003)

\subsubsection{Innovation Performance}

Yang et al. (2015) has examined the impact of centralization on innovation performance in 60 firms of China. The presence of entrepreneurial orientation of leader and employees determines performance of the firm in terms of innovation. Entrepreneurial orientation helps the leader and other employees to solicit for innovative solutions to a problem. Thus entrepreneurial leadership can lead to the innovative performance of the firm.

\subsubsection{Startup Performance}

Along the same line as discussed above, CEOs and employees of 102 startup firms were examined. In the study, it has been found that the transactional, transformational and laissez-faire leadership are a significantly predict start-up performance (Zaech \& Baldegger, 2017).

\subsubsection{Employee Voice}

Since leaders provide an opportunity and autonomy to the followers. In response, followers behave in way to manifest propositions and ideas for the benefit of firm (Dedahanov, Lee, Rhee, \& Yoon, 2016). Thus entrepreneurial leadership can also lead to employee voice behavior in an organization.

\subsubsection{Creativity}

Wu et al. (2008) has found the significant impact of promotion focus and prevention focus of leader's behavior on the creativity of employees. Promotion focus leaders strive for maximizing goal and are success oriented while prevention focus leaders avoid failure and risk and attempt for minimizing goals. Thus the presence of prevention focus behavior in leader will reduce the creativity of employees while the creativity of employees will enhance if the leader is promotion focus. Sklaveniti (2017) concentrated on creativity and co-action of members of ventures leading to the emergence of entrepreneurial leadership in small to medium size firms.

Table 3. Summary of possible outcomes of entrepreneurial leadership

\begin{tabular}{ll}
\hline Outcomes & References \\
\hline Strategic management of resources & (Ireland et al., 2003) \\
Wealth Creation & (Ireland et al., 2003), (Mccarthy et al., 2010) \\
Innovation performance & (Z. Yang et al., 2015), (Rutherford et al., 2003), (Chen, 2007) \\
New Venture or Startup Performance & (Zaech \& Baldegger, 2017), (Ensley, Pearce, \& Hmieleski, 2006) \\
Employee Voice & (Dedahanov et al., 2016) \\
Creativity & (Wu et al., 2008), (Sklaveniti, 2017), (Chen, 2007), (Cai et al., 2018), (Dedahanov et \\
& al., 2016) \\
\hline
\end{tabular}

\subsection{Possible Moderators of Entrepreneurial Leadership}

In the prior literature, specific attributes are solely linked to Entrepreneurial Leadership. Absence or presence of these attributes can influence the process of entrepreneurial leadership (Bagheri \& Pihie, 2011; Ensley et al., 2006; Gupta et al., 2004; Renko et al., 2015; Soriano \& Martínez, 2007):

- Performance-oriented: setting the high benchmark for the performance.

- Ambitious: setting challenging goals and working hard to achieve the same

- Informed: having set of tacit as well as explicit knowledge

- Extra Insight: they have intuition or forethought.

- Visionary: leaders are imaginary and tend to set high vision for the future

- Foresight: easily foresee future happening

- Confidence Builder: leaders Inculcate confidence in others

- Diplomatic: considerate and have excellent interpersonal relationships with the followers

- Effective Bargainer: good at negotiating with internal as well as external stakeholders 
- Convincing: ability to convince others and persuade others of their viewpoints.

- Encourage: able to build confidence and hope in the followers

- Inspirational: inspire followers and enhances their motivation to work

- Enthusiastic: inculcating positive feeling and sentiment for work

- Team Builder: leaders can build team and the strength to work together

- Improvement-oriented: always ready to seek and enhance performance of the team and followers

- Integrator: able to blend the work of each member and cohesiveness

- Intellectual Simulation: motivate others to participate and inspire them to use their use their intelligence and intellect at work

- Positive: leaders are always pragmatic and confident

- Decisive: swift in decision-making

- Employee Empowerment: share of authority and power from leader to followers so that followers don't have a sense of powerlessness.

- Entrepreneurial Self-Efficacy: followers should have belief that they are creative and can accomplish the task because entrepreneurial self-efficacy of followers influences the outcomes of entrepreneurial leadership

- Entrepreneurial Passion: passion and emotions to engage in entrepreneurial tasks influences the susceptibility towards the entrepreneurial leadership style.

- Contextual Aspect of organization: Crisis situation, availability of resources, strategic orientation, entrepreneurial orientation, top management support and competitive markets are context which influence the entrepreneurial leadership

- Pro-active: Ability of taking active steps towards future in identifying opportunities rather than waiting for the future.

- Environmental Dynamism: Uncertainty for the leader and organization due to dubious and swift change in the environments also influences entrepreneurial leadership.

Table 4. Summary of moderators of entrepreneurial leadership

\begin{tabular}{ll}
\hline Moderators-References & Explanation \\
\hline Performance-oriented- Leader level (Gupta et al., 2004) & Setting the high benchmark for the performance \\
Ambitious- Leader level (Gupta et al., 2004) & Setting challenging goals and working hard to achieve the same \\
Informed- Leader level (Gupta et al., 2004) & Having set of tacit as well as explicit knowledge \\
Extra Insight- Leader level (Gupta et al., 2004) & They have intuition or forethought \\
Visionary- Leader level (Gupta et al., 2004) & Leaders are imaginary and tend to set high vision for the future \\
Foresight Leader level (Gupta et al., 2004) & Easily foresee future happening \\
Confidence Builder- Leader level (Gupta et al., 2004) & Leaders Inculcate confidence in others \\
Diplomatic- Leader level (Gupta et al., 2004) & Considerate and have excellent interpersonal relationships with \\
& the followers \\
Effective Bargainer- Leader level (Gupta et al., 2004) & Good at negotiating with internal as well as external stakeholders \\
Convincing- Leader level (Gupta et al., 2004) & Able to convince others and persuade others of their viewpoints. \\
Encourage- Leader level (Gupta et al., 2004) & Able to build confidence and hope in the followers \\
Inspirational- Leader level (Gupta et al., 2004) & Inspire followers and enhances their motivation to do hard work \\
Enthusiastic- Leader level(Gupta et al., 2004) & Inculcating positive feeling and sentiment for work \\
Team Builder- Leader level (Gupta et al., 2004) & Leaders can build the team and the strength to work together \\
Improvement-oriented- Leader level (Gupta et al., & Always ready to seek and enhance the performance of the team \\
2004) & and followers \\
Integrator- Leader level (Gupta et al., 2004) & Able to blend the work of each member and cohesiveness \\
Intellectual Simulation- Leader level (Gupta et al., & Motivate others to participate and inspire them to use their use \\
their intelligence and intellect at work \\
Positive- Leader level (Gupta et al., 2004) & Leaders are always pragmatic and confident \\
Decisive- Leader level (Gupta et al., 2004) & Swift in decision-making \\
\hline
\end{tabular}


Pro-active-Leader level (Renko et al., 2015)

Employee Empowerment- Follower level (Renko et al., 2015)

Entrepreneurial Self-Efficacy- Follower level (Renko et al., 2015),(Newman, Tse, Schwarz, \& Nielsen, 2018)

Entrepreneurial Passion- Follower level (Renko et al., 2015)

Contextual Aspect of organization-Organizational level (Renko et al., 2015), (Vecchio, 2003), (Sklaveniti, 2017)

Environmental Dynamism-Organizational Level (Ensley et al., 2006)
Ability of taking active steps towards future in identifying opportunities rather waiting for the future.

Share of authority and power form leader to followers

Followers should have belief that they can accomplish the task because entrepreneurial self-efficacy of followers influences the outcomes of entrepreneurial leadership

Passion and emotions to engage in entrepreneurial tasks influences the susceptibility towards the entrepreneurial leadership style

Crisis situation, availability of resources, strategic orientation, entrepreneurial orientation, top management support, competitive markets

Uncertainty for the leader and organization due to dubious and swift change in the environments

Table 5. Top journals in which articles on the entrepreneurial leadership appears

\begin{tabular}{cc}
\hline Journals & Number of articles \\
\hline Journal of Small Business Management & 7 \\
International Small Business Journal & 6 \\
Small Business Economics & 4 \\
Entrepreneurship Theory and Practice & 3 \\
Journal of Business Venturing & 3 \\
\hline
\end{tabular}

\section{Number of articles}
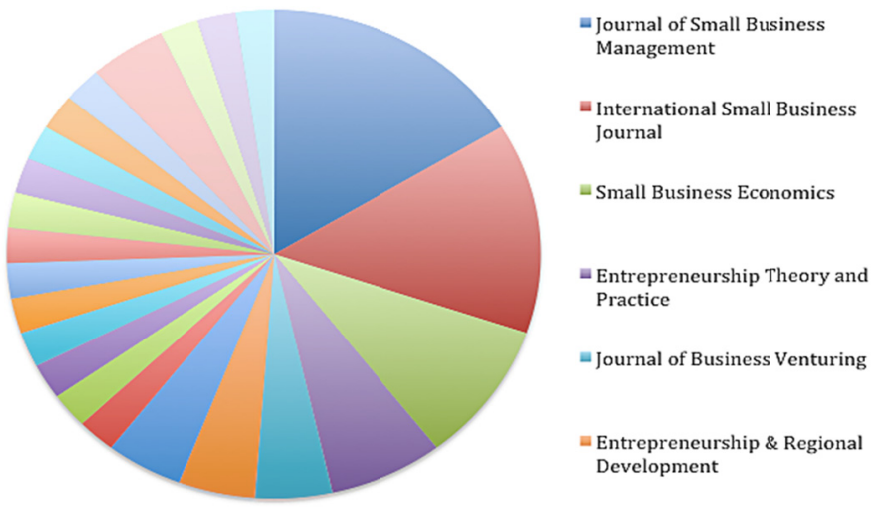

Figure 1. Top 5 Journals in which articles on the entrepreneurial leadership appears

Table 6. Research Methods used in the different studies

\begin{tabular}{cc}
\hline Research Methods & Number of articles \\
\hline Qualitative (Case Study/Interviews/Narratives/Structured Observations) & 18 \\
Quantitative (Regression/SEM) & 17 \\
Literature Review & 12 \\
Experimental Design & 1 \\
Proposition Paper & 2 \\
\hline
\end{tabular}

\section{Conclusions}

In the present study, we extracted the opportunity to review studies on the entrepreneurial leadership and the related field. We identified and presented different definitions and measures used in the prior literature to explain the concept of entrepreneurial leadership.

Specific roles such as framing the challenge, absorbing uncertainty, presence of human capital covering 
intellectual capital such as skills, knowledge, prior managerial experience, negotiation ability with the internal as well as external stakeholders, social capital in terms of their contacts within the business network and social group aids the leaders to develop entrepreneurial leadership

Entrepreneurial leaders have specific attributes such as they have extra insight, sense-making of business failure, highly ambitious, the presence of intellectual stimulation, right integrator, ability to make fast decision, positive attitude and traits such proactive personality moderate the process of entrepreneurial leadership.

In the current study, we have found some possible outcomes of entrepreneurial leadership such as wealth creation, firm performance, innovation performance and strategic management of resources. The present study contributes to the literature by extending the scope of literature on entrepreneurial leadership and may provide the insights into studies related to entrepreneurial leadership for future research.

\section{References}

Amir, S., Hejazi, M., Maleki, M. M., \& Naeiji, M. J. (2012). Designing a scale for measuring entrepreneurial leadership in SMEs. International Conference on Economics Marketing and Management, 28, 71-77.

Bagheri, A., \& Pihie, Z. A. L. (2011). Entrepreneurial leadership: Towards a model for learning and development. Human Resource Development International, 14(4), 447-463. https://doi.org/10.1080/13678868.2011.601594

Bodolica, V., \& Spraggon, M. (2015). Life on heels and making deals: A narrative approach to female entrepreneurial experiences in the UAE. Management Decision. https://doi.org/10.1108/09574090910954864

Boni, A., Weingart, L., \& Evenson, S. (2009). Innovation in an academic setting: Designing and leading a business through market-focused, interdisciplinary teams. Academy of Management Learning and Education, 8(3), 407-417. https://doi.org/10.5465/AMLE.2009.44287939

Brush, B. B., \& C. (2002). A_gendered_perspective_on_organizational.pdf.

Byrne, O., \& Shepherd, D. A. (2015). Different Strokes for Different Folks: Entrepreneurial Narratives of Emotion, Cognition, and Making Sense of Business Failure. Entrepreneurship: Theory and Practice, 39(2), 375-405. https://doi.org/10.1111/etap.12046

Cai, W., Lysova, E. I., Khapova, S. N., \& Bossink, B. A. G. (2018). Does Entrepreneurial Leadership Foster Creativity Among Employees and Teams? The Mediating Role of Creative Efficacy Beliefs. Journal of Business and Psychology, 1-15. https://doi.org/10.1007/s10869-018-9536-y

Charan, R., Hofer, C. W., \& Mahon, J. F. (1980). From Entrepreneurial to Professional Management: A Set of Guidelines. Journal of Small Business Management, 18(1), 1-10. https://doi.org/Article

Chen, M. H. (2007). Entrepreneurial leadership and new ventures: Creativity in entrepreneurial teams. Creativity and Innovation Management, 16(3), 239-249. https://doi.org/10.1111/j.1467-8691.2007.00439.x

Cope, J., Kempster, S., \& Parry, K. (2011). Exploring distributed leadership in the small business context. International Journal of Management Reviews, 13(3), 270-285. https://doi.org/10.1111/j.1468-2370.2011.00307.x

Cunningham, J. B., \& Lischeron, J. (1991). Defining Entrepreneurship. Journal of Small Business Management, 29(1), 45-61. https://doi.org/10.1504/IJESB.2007.014395

Dean, H., \& Ford, J. (2017). Discourses of entrepreneurial leadership: Exposing myths and exploring new approaches. International Small Business Journal, 35(2), 178-196. https://doi.org/10.1177/0266242616668389

Dedahanov, A. T., Lee, D. H., Rhee, J., \& Yoon, J. (2016). Entrepreneur's paternalistic leadership style and creativity: The mediating role of employee voice. Management Decision, 54(9), 2310-2324. https://doi.org/http://dx.doi.org/10.1108/MRR-09-2015-0216

Destler, \& McArthur, C. (1946). Economic History Association Entrepreneurial Leadership Among the " Robber Barons ": A Trial Balance Author ( s ): Chester McArthur Destler Source: The Journal of Economic History, Vol . 6, Supplement: The Tasks of Economic Published by: Cambridge Un. The Journal of Economic History, 6, 28-49.

Ensley, M. D., Pearce, C. L., \& Hmieleski, K. M. (2006). The moderating effect of environmental dynamism on the relationship between entrepreneur leadership behavior and new venture performance. Journal of 
Business Venturing, 21(2), 243-263. https://doi.org/10.1016/j.jbusvent.2005.04.006

F. Durker, P. (2015). The discipline of innovation. Proceedings of the Human Factors and Ergonomics Society, 2015-Janua, 303. https://doi.org/10.1177/1541931215591062

Galloway, L., Kapasi, I., \& Sang, K. (2015). Entrepreneurship, Leadership, and the Value of Feminist Approaches to Understanding Them. Journal of Small Business Management, 53(3), 683-692. https://doi.org/10.1111/jsbm. 12178

Gartner, W. B. (2011). When words fail: An entrepreneurship glossolalia. Entrepreneurship and Regional Development, 23(1), 9-21. https://doi.org/10.1080/08985626.2011.540405

Gartner, W., \& Liao, J. (2017). The effects of perceptions of risk, environmental uncertainty , and growth aspirations on new venture creation success Author (s): William Gartner and Jianwen Liao Stable URL : http://www.jstor.org/stable/41682934 REFERENCES Linked references are avail, 39(3), 703-712. http://www.jstor.org/stable/41682934

Gupta, V., MacMillan, I. C., \& Surie, G. (2004). Entrepreneurial leadership: Developing and measuring a cross-cultural construct. Journal of Business Venturing, 19(2), 241-260. https://doi.org/10.1016/S0883-9026(03)00040-5

Hamilton, E. (2006). Whose story is it anyway?: Narrative accounts of the role of women in founding and establishing family businesses. International Small Business Journal, 24(3), 253-271. https://doi.org/10.1177/0266242606063432

Ireland, R. D., Hitt, M. A., \& Sirmon, D. G. (2003). A model of strategic enterpreneurship: The construct and its dimensions. Journal of Management, 29(6), 963-989. https://doi.org/10.1016/S0149-2063(03)00086-2

Jayawarna, D., Jones, O., \& Macpherson, A. (2011). New business creation and regional development: Enhancing resource acquisition in areas of social deprivation. Entrepreneurship and Regional Development, 23(9-10), 735-761. https://doi.org/10.1080/08985626.2010.520337

Kempster, S., \& Cope, J. (2010). Article Information :Learning to lead in the entrepreneurial context Stephen. International Journal of Entrepreneurial Behavior \& Research, 1-6. https://doi.org/10.1108/EL-01-2014-0022

Koryak, O., Mole, K. F., Lockett, A., Hayton, J. C., Ucbasaran, D., \& Hodgkinson, G. P. (2015). Entrepreneurial leadership, capabilities and firm growth. International Small Business Journal, 33(1), 89-105. https://doi.org/10.1177/0266242614558315

Lechner, C. M., Sortheix, F. M., Obschonka, M., \& Salmela-Aro, K. (2018). What drives future business leaders? How work values and gender shape young adults' entrepreneurial and leadership aspirations. Journal of Vocational Behavior, 107(March), 57-70. https://doi.org/10.1016/j.jvb.2018.03.004

Leitch, C. M., Mcmullan, C., \& Harrison, R. T. (2013). The Development of Entrepreneurial Leadership: The Role of Human, Social and Institutional Capital. British Journal of Management, 24(3), 347-366. https://doi.org/10.1111/j.1467-8551.2011.00808.x

Leitch, C. M., \& Volery, T. (2017). Entrepreneurial leadership: Insights and directions. International Small Business Journal, 35(2), 147-156. https://doi.org/10.1177/0266242616681397

Lewis, K. V. (2015). Enacting Entrepreneurship and Leadership: A Longitudinal Exploration of Gendered Identity Work. Journal of Small Business Management, 53(3), 662-682. https://doi.org/10.1111/jsbm.12175

Louisa A. Huxtable-Thomas, Paul D Hannon, S. W. T. (2016). Article Information :An investigation into the role of emotion in leadership development for entrepreneurs: A four interface model. International Journal of Entrepreneurial Behavior \& Research, 1-6. https://doi.org/10.1108/EL-01-2014-0022

Mccarthy, D. J., Puffer, S. M., Darda, S. V, Mccarthy, D. J., Puffer, S. M., \& Darda, S. V. (2010). Convergence in Entrepreneurial Leadership Style: Evidence from Russia. California Management Review.

Mcgowan, P., Cooper, S., Durkin, M., \& O'Kane, C. (2015). The Influence of Social and Human Capital in Developing Young Women as Entrepreneurial Business Leaders. Journal of Small Business Management, 53(3), 645-661. https://doi.org/10.1111/jsbm.12176

Newman, A., Tse, H. H. M., Schwarz, G., \& Nielsen, I. (2018). The effects of employees' creative self-efficacy on innovative behavior: The role of entrepreneurial leadership. Journal of Business Research, 89(March), 1-9. https://doi.org/10.1016/j.jbusres.2018.04.001 
Ng, W., \& Thorpe, R. (2010). Not another study of great leaders. International Journal of Entrepreneurial Behavior \& Research, 16(5), 457-476. https://doi.org/10.1108/13552551011071896

Nicholls, A. (2010). E T \& P The Legitimacy of Social, 44(0), 611-634.

Prabhu, G. N. (1999). social enttrepreneurial leadership Career Development International Ganesh N- Prabhu.

Renko, M., El Tarabishy, A., Carsrud, A. L., \& Brännback, M. (2015). Understanding and measuring entrepreneurial leadership style. Journal of Small Business Management, 53(1), 54-74. https://doi.org/10.1111/jsbm.12086

Ribeiro Soriano, D., \& Manuel Comeche Martínez, J. (2007). Transmitting the entrepreneurial spirit to the work team in SMEs: The importance of leadership. Management Decision, 1-6. https://doi.org/10.1108/EL-01-2014-0022

Rutherford, M. W., Buller, P. F., \& McMullen, P. R. (2003). Human resource management problems over the life cycle of small to medium-sized firms. Human Resource Management, 42(4), 321-335. https://doi.org/10.1002/hrm.10093

Shepherd, D., \& Haynie, J. M. (2009). E T \& P and an Expedited Entrepreneurial Process: Identity Conflict, (812), 1245-1265.

Sklaveniti, C. (2017). Processes of entrepreneurial leadership: Co-acting creativity and direction in the emergence of new SME ventures. International Small Business Journal, 35(2), 197-213. https://doi.org/10.1177/0266242616673420

Surie, G., \& Ashley, A. (2012). Creation and Ethics Integrating Pragmatism in Entrepreneurial Leadership for Sustainable Value Creation Gita Surie. Journal of Business Ethics, 81(1), 235-246. https://doi.org/10.1007/s10551-007-9491-4

Van der Heyden, L., Blondel, C., \& Carlock, R. S. (2005). Fair process: Striving for justice in family business. Family Business Review, 18(1), 1-21. https://doi.org/10.1111/j.1741-6248.2005.00027.x

Vecchio, R. P. (2003). Entrepreneurship and leadership: Common trends and common threads. Human Resource Management Review, 13(2), 303-327. https://doi.org/10.1016/S1053-4822(03)00019-6

Waistad, W. B., \& Kourilsky, M. L. (1998). Entrepreneurial Attitudes and Knowledge of Black Youth. Entrepreneurship: Theory \& Practice, 23(2), 5-18. Retrieved from http://0-search.ebscohost.com.millenium.itesm.mx/login.aspx\%3Fdirect\%3Dtrue\%26db\%3Dbuh\%26AN\% 3D2165294\%26lang\%3Des\%26site\%3Deds-live

Wang, C. L., Tee, D. D., \& Ahmed, P. K. (2012). Entrepreneurial leadership and context in Chinese firms: A tale of two Chinese private enterprises. Asia Pacific Business Review, 18(4), 505-530. https://doi.org/10.1080/13602381.2012.690257

Wu, C., McMullen, J. S., Neubert, M. J., \& Yi, X. (2008). The influence of leader regulatory focus on employee creativity. Journal of Business Venturing, 23(5), 587-602. https://doi.org/10.1016/j.jbusvent.2007.09.005

Yang, Q., Zimmerman, M., \& Jiang, C. (2011). Characteristics on New Firms ' Time to IPO*. Journal of Small Business Management, 49(2), 163-184. https://doi.org/10.1111/j.1540-627X.2011.00320.x

Yang, Z., Zhou, X., \& Zhang, P. (2015). Centralization and innovation performance in an emerging economy: testing the moderating effects. Asia Pacific Journal of Management, 32(2), 415-442. https://doi.org/10.1007/s10490-014-9394-8

Zaech, S., \& Baldegger, U. (2017). Leadership in start-ups. International Small Business Journal, 35(2), 157-177. https://doi.org/10.1177/0266242616676883

\section{Copyrights}

Copyright for this article is retained by the author(s), with first publication rights granted to the journal.

This is an open-access article distributed under the terms and conditions of the Creative Commons Attribution license (http://creativecommons.org/licenses/by/4.0/). 